\title{
Pengaruh Penambahan Ikan Lele (Clarias gariepinus) terhadap Sifat Organoleptik Slondok
}

\author{
Heni Purwanti ${ }^{\mathrm{a}, 1, *}$, Intan Jd Habibie ${ }^{\mathrm{b}, 2}$ \\ ${ }^{a}$ SMK Negeri 4 Yogyakarta, Jl. Sidikan No 60 Yogyakarta, 55161, Indonesia \\ ${ }^{b}$ Dinas Pertanian, Tanaman Pangan dan Holtikultura Provinsi Gorontalo, Jl. Thayeb Gobel Komplek Blok Plan \\ Perkantoran Prov. Gorontalo, 96125, Indonesia \\ ${ }^{1}$ henipurwanti_smkn4@yahoo.com, ${ }^{2}$ intan.habibie445@gmail.com \\ * penulis korespondensi
}

\begin{abstract}
Slondok is a snack that uses the main ingredient of cassava. As a snack that resembles a cracker, slondok is tasty, crunchy and light as a snack. The savory taste of slondok is usually due to the addition of seasonings in the form of salt, coriander, garlic and artificial flavor enhancers from chemicals. To reduce the use of chemicals, slondok is made with the addition of catfish. It is hoped that protein-rich catfish can replace chemicals to strengthen the savory taste of slondok as well as increase the nutritional value of slondok. This experimental research aims to determine the addition of catfish to slondok which is preferred by consumers. The results showed that the addition of catfish by $15 \%$ to $25 \%$ in slondok had a preferred level of preference.
\end{abstract}

Keywords: cassava, catfish, organoleptic properties, slondok

\section{ABSTRAK}

Slondok merupakan makanan ringan yang menggunakan bahan utama ubi kayu. Sebagai makanan ringan yang menyerupai kerupuk, slondok mempunyai sifat gurih, renyah dan ringan sebagai camilan. Rasa gurih pada slondok biasanya karena penambahan bumbu berupa garam, ketumbar, bawang putih dan penguat rasa buatan dari bahan kimia. Untuk mengurangi pemakaian bahan kimia, maka dibuat slondok dengan penambahan ikan lele. Ikan lele yang kaya protein diharapkan dapat menggantikan bahan kimia untuk menguatkan rasa gurih pada slondok selain juga dapat meningkatkan nilai gizi slondok. Penelitian eksperimen ini bertujuan untuk mengetahui penambahan ikan lele pada slondok yang disuka oleh konsumen. Hasil penelitian menunjukkan bahwa penambahan ikan lele sebesar $15 \%$ sampai $25 \%$ pada slondok mempunyai tingkat kesukaan disukai.

Kata Kunci: ikan lele, sifat organoleptik, slondok, ubi kayu

\section{Pendahuluan}

Ubi kayu atau kasava (Manihot utilisima) sebagai bahan dasar pembuatan slondok adalah merupakan tanaman pokok di daerah tropis, tanaman ini dapat memberikan hasil yang tinggi meskipun tumbuh pada lahan yang kurang subur atau lahan dengan curah hujan yang rendah (Nugraheni, 2016). Selain sifat-sifat di atas, tanaman ubi kayu tidak memerlukan perawatan yang rumit tetapi tidak tahan terhadap suhu dingin. Ubi kayu selain banyak mengandung air dan pati juga mengandung asam sianida ( $\mathrm{HCN})$ yang rasanya pahit dan sifatnya beracun (Warsito, 2015). Pada umumnya masyarakat telah mengetahui cara menghilangkan racun asam sianida, yaitu dengan cara merendam ubi kayu dalam air 
selama beberapa waktu sebelum dilakukan pengolahan. Ubi kayu menyediakan energi pangan terutama dari umbinya yang mudah dicerna dan juga memberikan kalori tetapi mengandung protein yang sedikit.

Ikan lele (Clarias gariepinus) merupakan salah satu jenis ikan yang hidup pada air tawar seperti sungai dan rawa-rawa, serta mampu bertahan hidup pada air yang keruh dan berlumpur. Ikan lele adalah salah satu jenis ikan yang saat ini sudah banyak dibudidayakan oleh petani ikan ataupun masyarakat umum, meskipun pemanfaatannya hanya sebagai bahan pangan yang dikonsumsi langsung sebagai ikan goreng atau ikan bakar dan masih jarang ditemukan pemanfaatan ikan lele menjadi produk olahan pangan (Pratama, 2019). Menurut Astawan (2008), kandungan gizi yang dimiliki ikan lele sangat banyak, komposisi gizi ikan lele meliputi kandungan protein (17,7\%), lemak $(4,8 \%)$, mineral $(1,2 \%)$, dan air $(76 \%)$. Protein menjadi komposisi zat gizi urutan kedua terbanyak dalam kandungan gizi ikan lele yaitu sebesar (17,7\%). Selain kandungan proteinnya, ikan lele juga mengandung karoten, vitamin A, fosfor, kalsium, zat besi dan vitamin B1 (Rosa, 2007). Selain komponen gizi yang dimiliki ikan lele, kelebihan lain ikan lele adalah komponen gizi ikan lele mudah dicerna dan diserap oleh tubuh (Rohimah, 2014).

Sebagian masyarakat tidak menyukai ikan lele dikarenakan bentuknya yang besar dan baunya yang khas. Oleh karena itu perlu dilakukan suatu upaya lain, untuk memanfaatkan ikan lele sebagai bahan pangan olahan pilihan. Salah satu upaya untuk meningkatkan konsumsi ikan lele maka diperlukan penambahan ikan lele terhadap produk olahan makanan. Penganekaragaman produk perikanan diharapkan dapat meningkatkan pendayagunaan dan usaha pengolahan hasil perikanan untuk diolah menjadi produk pangan yang bergizi tinggi, enak, murah, dan mudah didapat. Upaya ini juga diharapkan dapat menigkatkan tingkat konsumsi ikan masyarakat Indonesia. Peningkatan tingkat konsumsi ikan di Indonesia dapat dilakukan dengan pemanfaatan sumberdaya ikan yang ada di Indonesia itu sendiri, salah satunya yaitu dengan menambahkan ikan kedalam produk makanan (Asyari, 2016).

Slondok adalah merupakan salah satu jenis makanan ringan yang terbuat dari parutan ubi kayu dan dibuat dengan berbagai macam perlakuan dan penambahan bumbu-bumbu. Slondok sudah lama dikenal dan disukai oleh berbagai kalangan masyarakat Indonesia, selain karena rasanya gurih asin dan ringan sebagai cemilan, harganya juga terjangkau masyarakat. Pada umumnya slondok berasa renyah dan gurih hampir mirip dengan rasa kerupuk. Gurihnya slondok yang berada dipasaran selama ini, selain karena diberikan bumbu-bumbu alami seperti bawang putih, ketumbar dan garam juga ditambahkan penguat rasa buatan dari bahan kimia, sehingga hal seperti ini akan membahayakan kesehatan tubuh apabila slondok dengan penguat rasa buatan dari bahan kimia yang berlebihan sering dikonsumsi oleh manusia. Penggunaan bahan kimia pada bahan pangan memang seharusnya dikurangi atau bahkan dihindari karena tidak bermanfaat bagi tubuh bahkan seringnya mengakibatkan gangguan kesehatan. Sehingga diperlukan inovasi untuk mengurangi atau bahkan menghilangkan penggunaan bahan kimia dalam bahan makanan.

Tujuan penelitian penambahan ikan lele pada pembuatan slondok adalah untuk mempertahankan rasa slondok supaya tetap gurih, meskipun tanpa penambahan penguat 
rasa buatan dari bahan kimia, sehingga akan lebih baik sebagai camilan sehat dan selain itu juga dapat meningkatkan nilai gizi slondok. Dengan demikian perlu dilakukan penelitian seberapa banyak penambahan ikan lele pada pembuatan slondok yang paling disukai oleh masyarakat.

\section{Metode Penelitian}

\subsection{Bahan dan Alat}

Bahan yang digunakan dalam pembuatan slondok adalah ubi kayu, ikan lele, bumbubumbu : bawang putih, ketumbar, garam dan minyak goreng. Alat-alat yang digunakan untuk membuat slondok antara lain dandang, kompor, wajan, pengaduk, baskom, timbangan, parut, blender, dan tampah.

\subsection{Pembuatan Slondok}

Sebelum dilakukan pembuatan slondok ubi kayu dengan penambahan ikan lele, disiapkan daging ikan lele giling terlebih dahulu. Diawali dengan langkah : membersihkan kan lele bagian dalam perut, dicuci bersih, dan dikukus selama 10 menit dengan tujuan supaya memudahkan saat pemisahan kulit ikan lele dan tulang dengan daging ikan lele. Di pisahkannya kulit ikan lele dari daging bertujuan supaya slondok yang dihasilkan tidak berwarna kehitaman karena adanya kulit ikan lele pada slondok. Daging ikan lele yang sudah bersih dari tulang dan kulit kemudian digiling sampai halus supaya memudahkan saat pencampuran dengan ubi kayu. Secara ringkas cara kerja pembuatan ikan lele giling dapat di lihat pada diagram alir Gambar 2.1 di bawah ini :

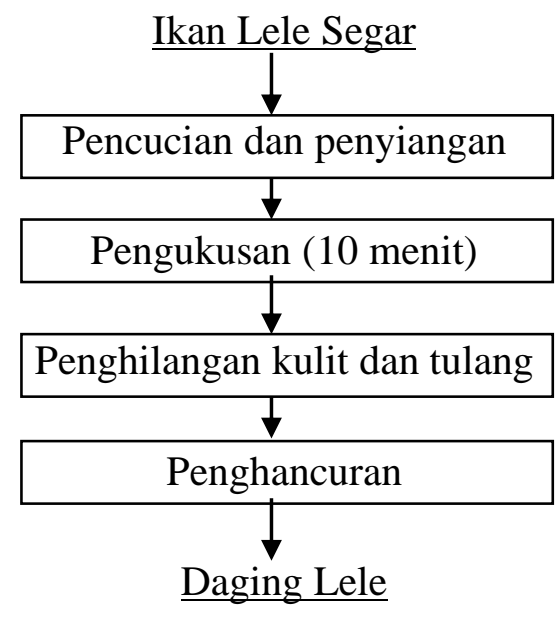

Gambar 2.1 Diagram Alir proses pembuatan daging lele giling

Setelah daging ikan lele selesai digiling, dilanjutkan membuat slondok ubi kayu dengan penambahan daging lele yang sudah digiling. Cara kerja dimulai dari pembuatan slondok kontrol terlebih dahulu, yaitu slondok tanpa penambahan daging ikan lele dan kemudian dilanjutkan membuat slondok ubi kayu dengan penambahan daging ikan lele giling (Tabel 2.1). 
Tabel 2.1 Perbandingan Antara Ubi Kayu dan Daging Lele

\begin{tabular}{lcccc}
\hline Perbandingan bahan & A & B & C & D \\
\hline Ubi Kayu (gram) & 100 & 85 & 75 & 65 \\
Daging lele (gram) & 0 & 15 & 25 & 35 \\
\hline
\end{tabular}

Selanjutnya langkah-langkah pembuatan slondok dengan penambahan daging lele mengikuti diagram alir pada Gambar 2.2 berikut ini :

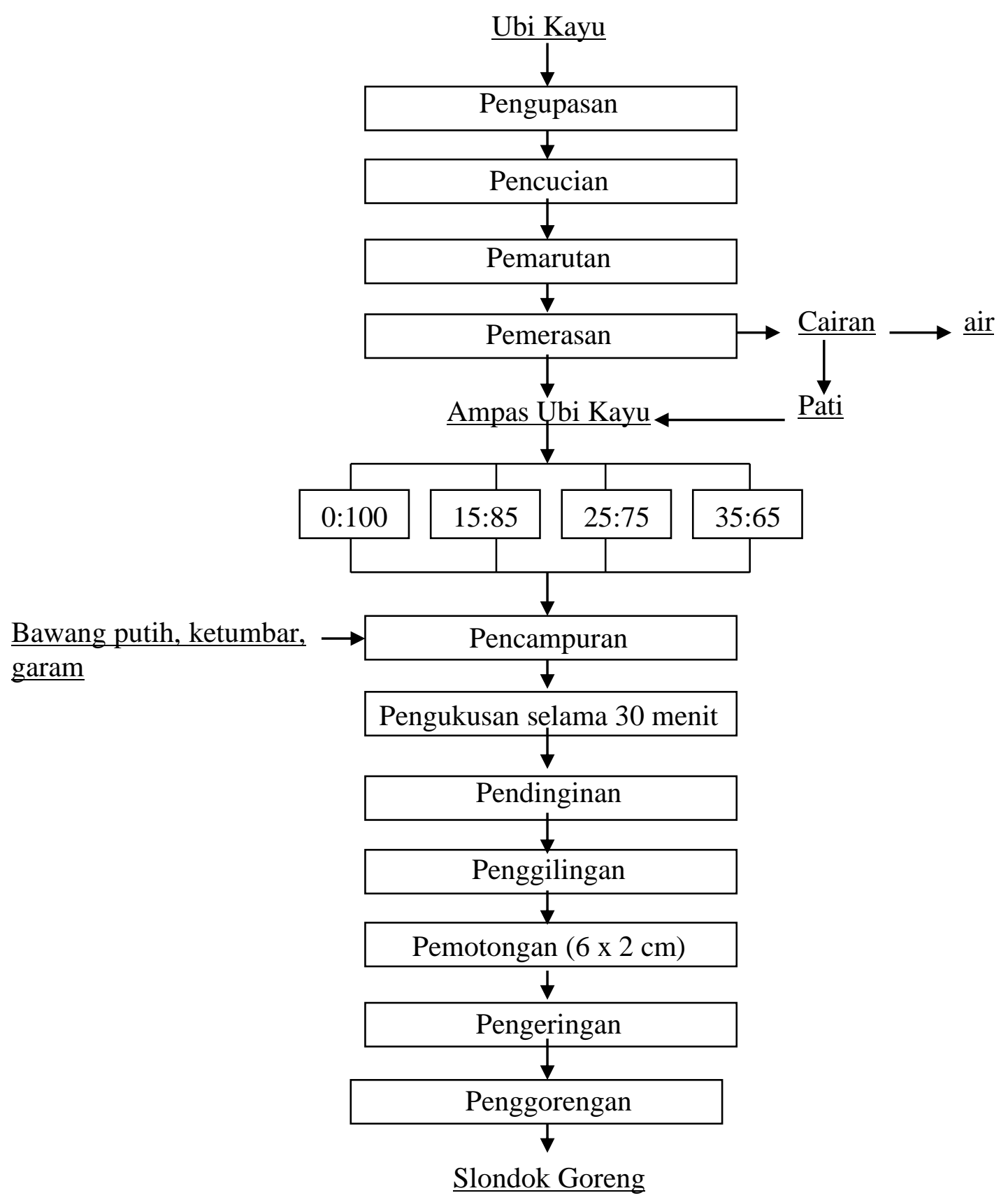

Gambar 2.2 Diagram Alir Proses Pembuatan Slondok dengan Penambahan Daging Ikan Lele 


\subsection{Rancangan Penelitian}

Untuk mengetahui pengaruh penambahan ikan lele terhadap sifat organoleptik slondok, maka digunakan Rancangan Percobaan Blok Acak Lengkap (Randomized Complete Block Design) untuk uji sensoris, sifat organoleptik slondok yang meliputi warna, rasa, tekstur atau kerenyahan dan kesukaan total dengan panelis semi terlatih (mahasiswa) sebanyak 20 orang dan dilaksanakan di ruang laboratorium pangan dan gizi.

\section{Hasil dan Pembahasan}

Berikut di bawah ini adalah tabel hasil pengujian oleh panelis semi terlatih terhadap slondok yang sudah digoreng, secara umum berdasar analisis organoleptic, slondok ubi kayu dengan perlakuan penambahan daging ikan lele perbandingan (A) 0:100, (B) 15:85, (C) 25:75, (D) 35:65 adalah

Tabel 3.1 Hasil Uji Organoleptik terhadap Slondok yang Sudah Digoreng

\begin{tabular}{|c|c|c|c|c|c|}
\hline Tipe Uji & A $(0 \%)$ & B $(15 \%)$ & $\mathrm{C}(25 \%)$ & $\mathrm{D}(35 \%)$ & Keterangan \\
\hline Warna & $1.20^{\mathrm{a}}$ & $2.65^{b}$ & $2.25^{b}$ & $3.85^{c}$ & $\begin{array}{l}\text { 1. Putih kekuningan } \\
\text { 2. Kuning Kecoklatan } \\
\text { 3. Coklat muda } \\
\text { 4. Coklat sekali }\end{array}$ \\
\hline Rasa & $4.00^{\mathrm{d}}$ & $2.70^{\mathrm{e}}$ & $1 ., 90^{f}$ & $1.15^{\mathrm{f}}$ & $\begin{array}{l}\text { 1. Rasa ikan sangat kuat } \\
\text { 2. Rasa Ikan kuat } \\
\text { 3. Rasa ikan agak kuat } \\
\text { 4. Rasa ikan tidak kuat }\end{array}$ \\
\hline Tekstur & $1.30^{\mathrm{g}}$ & $1.65^{\mathrm{g}}$ & $2.75^{\mathrm{h}}$ & $3.75^{\mathrm{i}}$ & $\begin{array}{l}\text { 1. Sangat renyah } \\
\text { 2. Renyah } \\
\text { 3. Kurang renyah } \\
\text { 4. Tidak renyah }\end{array}$ \\
\hline $\begin{array}{l}\text { Kesukaan } \\
\text { Total }\end{array}$ & $3.85^{j}$ & $1.65^{\mathrm{k}}$ & $1.20^{\mathrm{k}}$ & $2.80^{1}$ & $\begin{array}{l}\text { 1. Sangat suka } \\
\text { 2. Suka } \\
\text { 3. Kurang suka } \\
\text { 4. Tidak suka }\end{array}$ \\
\hline
\end{tabular}

Tabel 3.1 merupakan hasil pengujian scoring slondok dengan penambahan daging ikan lele, slondok A sebagai kontrol yang mempunyai sifat putih kekuningan dengan rasa ikan lele yang tidak kuat dan sangat renyah. Berdasarkan tabel diatas, analisis varian menunjukkan adanya pengaruh nyata antara perlakuan. Nilai warna slondok bervariasi antara putih kekuningan sampai mendekati coklat sekali (1,2-3,85). Uji Duncan's Multiple Range Test (DMRT) pada taraf significant 5\% menunjukkan slondok dari ubi kayu murni sebagai kontrol (A) berbeda nyata dengan slondok penambahan ikan lele sebesar 15\% (B), (C) 25\%) dan (D) 35\%. Sedangkan slondok B tidak berbeda nyata dengan slondok C, tetapi berbeda nyata dengan slondok D. Antara slondok C dan D berbeda nyata.

Warna coklat yang terjadi pada slondok disebabkan karena kandungan pati yang ada pada bahan, pati yang memiliki sifat akan berubah menjadi kecoklatan atau browning jika 
terkena panas (Koswara, 2009). Berdasar tabel 3.1. warna slondok cenderung semakin coklat seiring dengan bertambahnya prosentase penambahan ikan lele, hal ini dipengaruhi oleh adanya reaksi maillard, yaitu reaksi yang terjadi antara karbohidrat khususnya gula pereduksi dengan gugus amino primer atau asam amino (Winarno, 1995). Kandungan gizi (protein) slondok dengan penambahan ikan lele pada slondok yang banyak mengandung karbohidrat karena menggunakan bahan dasar ubi kayu, sehingga gula pereduksi pada slondok akan bereaksi dengan gugus amina primer dari protein lele yang menghasilkan pigmen melanoidin menyebabkan warna coklat pada slondok. Hal ini sejalan dengan penelitian Priyanto (2020) yang menyatakan semakin banyak penambahan ikan lele pada amplang maka warna amplang semakin coklat.

Rasa pada suatu produk olahan yang menentukan penerimaan kosumen, salah satunya yaitu tingkat kegurihan. Pada penelitian ini kegurihan slondok selain disebabkan oleh bumbu-bumbu yang ditambahkan seperti bawang putih, ketumbar dan garam, rasa gurih slondok juga dipengaruhi oleh prosentase penambahan ikan lele pada slondok. Pengujian terhadap rasa slondok menunjukkan adanya pengaruh nyata antara masing-masing perlakuan. Nilai rasa berkisar antara 1,15 sampai 4 yang berarti antara slondok rasa ikan lele sangat kuat sampai slondok dengan rasa ikan lele tidak kuat. Uji DMRT 5\% menunjukkan slondok kontrol (A) berbeda nyata dengan slondok B, C, dan D. Slondok B berbeda nyata dengan slondok $\mathrm{C}$ dan $\mathrm{D}$, sedangkan antara slondok $\mathrm{C}$ dan $\mathrm{D}$ tidak berbeda nyata dalam hal rasa. Kondisi data penelitian sejalan dengan perlakuan penelitian, semakin banyak ikan lele ditambahkan ke dalam slondok maka semakin kuat rasa ikan lele pada slondok. Ikan lele yang identik dengan rasa gurih serta aroma yang kuat karena adanya protein dalam ikan lele sehingga memberikan rasa slondok yang gurih.

Tekstur merupakan faktor yang berpengaruh terhadap penilaian, karena tekstur suatu makanan akan terasa saat konsumen mengkonsumsi makanan tersebut. Sehingga tekstur merupakan salah satu aspek yang penting bagi kualitas makanan, bahkan terkadang lebih diperhatikan dibanding dengan rasa dan kenampakan. Demikian juga pada slondok yang merupakan makanan camilan kering, tekstur akan menjadi perhatian utama. Tekstur, terkait dengan kerenyahan slondok pada penelitian ini, semakin rendah hasil penilaian tekstur maka slondok semakin renyah, dan sebaliknya semakin tinggi nilai tekstur maka semakin keras tekstur slondok atau slondok semakin tidak renyah. Hasil pengujian DMRT $5 \%$ terhadap tekstur slondok menunjukkan adanya perbedaan yang nyata diantara masingmasing perlakuan. Nilai berkisar antara 1,30 sampai 3,75 yang berarti antara sangat renyah sampai kurang renyah. Untuk slondok kontrol (A) tidak berbeda berbeda nyata dengan slondok B, tetapi berbeda nyata dengan slondok $\mathrm{C}$ dan $\mathrm{D}$, slondok $\mathrm{B}$ berbeda nyata dengan slondok $\mathrm{C}$ dan juga dengan slondok $\mathrm{D}$, antara slondok $\mathrm{C}$ dan $\mathrm{D}$ juga berbeda nyata.

Pada Tabel 3.1 terlihat bahwa meningkatnya penambahan ikan lele pada slondok mempengaruhi kerenyahan slondok, slondok akan semakin kurang renyah atau bahkan tidak renyah. Hal ini terjadi karena gel protein pada ikan lele diikat oleh granula pati selama penggorengan atau pemanasan sehingga granula menjadi mengembang dan mendesak matriks protein dan pada saat yang bersamaan matriks protein kehilangan air yang menyebabkan gel protein menjadi lebih padat dan kompak Deman (1997) dalam Widjaya (2015). Akibat dari reaksi diatas, maka semakin banyak penambahan ikan lele 
pada slondok menyebabkan tekstur slondok menjadi tambah keras, kurang renyah atau bahkan tidak renyah. Hal ini sejalan dengan penelitian yang dilakukan oleh Asyari (2016), bahwa semakin banyak penambahan surimi lele pada donat ubi jalar, menyebabkan tekstur donat menjadi lebih keras.

Selain karena faktor diatas, berkurangnya kerenyahan slondok kemungkinan disebabkan karena perbedaan kadar air antara ubi kayu dengan ikan lele. Ikan lele mempunyai kadar air lebih tinggi dibanding dengan ubi kayu, selain itu perlakuan pendahuluan setelah pemarutan ubi kayu dilakukan pemerasan sampai keluar cairan yang terdiri dari pati dan air, airnya kemudian dibuang dan hanya diambil pati nya saja. Perlakuan pendahuluan tersebut membuat turunnya kadar air pada ubi kayu. Dengan demikian semakin banyak ikan lele yang ditambahkan pada slondok akan menyebabkan kadar air slondok juga tinggi. Kadar air yang tinggi menyebabkan teksstur slondok menjadi keras sehingga slondok menjadi kurang renyah atau bahkan tidak renyah.

Hasil pengujian kesukaan total (Hedonic Test) menunjukkan adanya pengaruh yang nyata antara perlakuan. Nilai kesukaan berkisar antara kurang suka $(3,85)$ sampai dengan sangat suka $(1,20)$ Uji DMRT 5\% menunjukkan bahwa slondok A sebagai kontrol, ada perbedaan nyata dengan slondok B, C ataupun slondok D. Sedangkan antara slondok B dengan slondok $\mathrm{C}$ tidak ada perbedaan nyata, tetapi antara slondok B dengan slondok D terdapat perbedaan nyata. Slondok C dengan slondok D terdapat perbedaan nyata. Slondok A sebagai slondok kontrol dinilai oleh panelis kurang disuka $(3,85)$ bahkan mendekati tidak disuka oleh panelis, hal ini kemungkinan rasa slondok A kurang gurih, karena tanpa ada penambahan ikan lele, dan bumbu yang diberikan hanya garam, bawang putih dan ketumbar tanpa ada tambahan penguat rasa buatan. Sedangkan slondok yang paling disuka adalah slondok $C(1,20)$ yaitu slondok dengan penambahan ikan lele sebesar $25 \%$ atau perbandingan 25:75, kemudian slondok $\mathrm{B}(1,65)$ dengan penambahan ikan lele sebesar 15\% atau perbandingan 15:85. Pada slondok B dan C, mempunyai rasa gurih meskipun bumbu yang ditambahkan sama dengan slondok A. Rasa gurih pada slondok B dan C dikarenakan adanya penambahan ikan lele. Selain gurih pada slondok B dan C juga renyah sehingga cocok sebagai makanan ringan seperti halnya kerupuk. Sedangkan slondok D mempunyai nilai 2,80 yang berarti dinilai antara suka sampai kurang suka, hal ini disebabkan karena kerenyahan slondok D yang kurang renyah, meskipun rasanya gurih.

\section{Kesimpulan}

Dari ketiga variasi perbandingan ubi kayu dan ikan lele pada pembuatan slondok yang sudah dilakukan dapat ditarik kesimpulan bahwa penambahan ikan lele pada pembuatan slondok memberikan pengaruh terhadap sifat organoleptic slondok berupa warna, rasa dan kerenyahan. Perbandingan antara ubi kayu dan ikan lele sebesar 25:75 adalah slondok yang paling disuka oleh panelis, kemudian disusul dengan perbandingan 15:85. 


\section{Pustaka}

Astawan, M., (2008), Sehat dengan Hidangan Hewani, Jakarta, Penebar Swadaya.

Asyari, M., Eddy Afriyanto, dan Rizky Intan Pratama, 2016, "Fortifikasi Surimi Lele Dumbo Sebagai Sumber Protein Terhadap Tingkat Kesukaan Donat Ubi Jalar", Jurnal Perikanan Kelautan, Vol. VII No. 2 /Desember 2016 (71-79)

Eka Pratama, Angga, Rosyid Ridho, Nadya Adharani, dan Any Kurniawati, 2019, Tepung Ikan Lele Dumbo Clarias Gariepinus Untuk Meningkatkan Kandungan Protein Pada Kue Terang Bulang, Jurnal Lemuru 1 (1), 18-25, https://doi.org/10.36526/lemuru.v1i1.408

Koswara, S., 2009, Pengolahan Aneka Kerupuk, E-Book pangan.com.

Nugraheni, Mutiara, 2016, Pengetahuan Bahan Pangan Nabati, Yogyakarta, Plantaxia.

Priyanto, Priyanto, Yuli Wibowo, dan Jay Jayus, 2020, Karakteristik Amplang Ikan Lele Dumbo (Clarias Gariepinus) Hasil Variasi Rasio Daging Ikan Lele Dan Tapioka, Jurnal Agrateknologi, Vol. 14 No. 02, 143-152

Rohimah, I., Etti, S., dan Ernawati, N., 2014, Analisis Energi dan Protein Serta Daya Terima Biskuit Tepung Labu Kuning dan Ikan Lele, Jurnal USU, https://jurnal.usu.ac.id/index.php/gkre/article/view/51602781. Diakses pada tanggal 15 Januari 2021.

Rosa, R., Bandarra N.M., dan Nunes, M.I., 2007, Nutritional Quality of African Cat Fish Clarias Geriepinus (Burcell 1822): A Positive Criterion for the Future Development of the European Production of Siluroidei. International Journal of Food Science \& Technology, 42 (3) 342-351

Warsito, Heri, Rindiani, dan Fata Nurdyansyah, 2015, Ilmu Bahan Makanan Dasar, Yogyakarta, Nuha Medika.

Widjaya, FP., Evi Liviawaty, dan Nia Kurniawati, 2015, Fortifikasi Protein Surimi Manyung terhadap tingkat kesukaan donat, Jurnal Perikanan dan Kelautan, Vol. 6 No. 2 (1)

Winarno, F.G., 1995, Enzim Pangan, Gramedia Pustaka Utama, Jakarta. 